\title{
Introduction to Volume 44
}

The forty-fourth volume of Barnboken: Journal of Children's Literature Research includes three themes which together reflect the wide span not only of Nordic fiction for young readers, but also of the research on Nordic children's and young adult literature. During 2021 Barnboken published 15 articles, the majority of which belonged to this year's three themes on poetry, silences and silencing, and translation, respectively. In addition, Barnboken published 15 reviews of recent Nordic and international theoretical literature.

The first guest theme, "Poetry for Children and Youth", is edited by Johan Alfredsson (PhD, University of Gothenburg) and Anne Skaret (Professor, Inland Norway University of Applied Sciences, Norway). It consists of seven articles that examine everything from poetry anthologies, nonsense and picturebooks to stage performances and poems originally intended for older target groups. The latter is a central issue in several of the contributions, and the analyses demonstrate how poetry questions and dissolves the boundaries between the normative categories of child, adolescent, and adult. Classic texts by for example Tove Jansson and Barbro Lindgren are examined, as well as more recent Nordic works by authors and artists such as Ingvild Rishøi, Bendik Kaltenborn, Birgitte Krogsbøll, and Kamilla Wichmann. The guest editors' introduction describes the theme's background and offers a more detailed presentation of the seven contributions.

"Silence and Silencing in Children's Literature", the second guest theme in this year's volume, originated from the IRSCL Congress 2019 on the same theme. Guest editors are Elina Druker (Professor, Stockholm University), Björn Sundmark (Professor, Malmö University), Åsa Warnqvist (Docent, the Swedish Institute for Children's Books), and Mia Österlund (Docent, Åbo Akademi University, Finland). Due to the great interest in the theme, it stretches across two volumes. It concludes in volume 44 with two contributions that shed light on children's books' potential to challenge silencing strategies, in the first article with the help of queer-theoretical tools and in the second by taking animal rights and earlier research on animals in children's literature as its starting point. Both articles, as well as the previous eight articles belonging to the theme, are presented in more depth in the guest editors' introduction.

(C2021 A. Warnqvist. This is an open access article distributed under the terms of the Creative Commons CC-BY-NC 4.0 License (https:/ / creativecommons.org/licenses/by-nc/4.0/), permitting all non-commercial use, distribution, and reproduction in any medium, provided the original work is properly cited.

Citation: Barnboken - tidskrift för barnlitteraturforskning/Barnboken: Journal of Children's Literature Research, Vol. 44, 2021 http://dx.doi.org/10.14811/clr.v44.655 
Moreover, the five spontaneously submitted contributions that form the theme "Translation" address translated children's and young adult literature from a variety of genres and language areas. Anna Vogel examines how the spirit of the age and production terms influence the protagonist Anne Shirley's character traits in Swedish translations of L. M. Montgomery's Anne of Green Gables (1908). Marcus Axelsson and Ragnhild Næsje analyze German, French, and British editions of Norwegian Maria Parr's works, with particular emphasis on the book covers and titles. Parr's authorship is also the focus of Marcus Axelsson and Charlotte Lindgren's article, where they take a closer look at the translation of foul language in the French and Swedish translations of Parr's Keeperen og havet (Lena, the Sea, and Me, 2017). Furthermore, the theme includes two contributions by Mari Mossberg. Her first article investigates gender-neutral and inclusive strategies in Swedish translations of French non-fiction. In her second article, Mossberg analyzes the Swedish translation of the bestseller phenomenon Good Night Stories for Rebel Girls: 100 Tales of Extraordinary Women (2016) by Elena Favilli and Francesca Cavallo, while also comparing it with the Danish, French, and Norwegian translations. The fact that as many as five manuscripts on translation were submitted to Barnboken around the same time demonstrates the great interest in this research area in the Nordic countries.

Finally, Ulf Boëthius's contribution in the section "Other Articles" examines an older work by Erik Pallin titled Kaparkaptenen på Emden: Romantiserad skildring från det stora världskriget 1914 (The Privateer Captain of Emden: Romanticized Depiction from the Great World War in 1914), published in December 1914. Boëthius illuminates the tension between fact and fiction in Pallin's depiction of the war. The analysis shows how Pallin downplays rather than accentuates the atrocities of real-life war in his novel, instead offering his readers a classic adventure story with both humorous and romantic elements.

Barnboken is an Open Access journal, which means that all articles and reviews are published online and are freely available on the journal's website and in full text through several international databases. The journal's focus is primarily Swedish and Nordic, but Barnboken has readers all over the world. During 2021, my fellow members of the editorial board were Maria Jönsson (Professor, Umeå University, Sweden), Anne Skaret (Professor, Inland Norway University of Applied Sciences, Norway), Olle Widhe (Professor, University of Gothenburg, Sweden), and Mia Österlund (Docent, Åbo Akademi University, Finland). Review editor during 2021 was research assistant 
Hanna Liljeqvist (the Swedish Institute for Children's Books). The journal's Advisory Board includes 15 prominent Nordic and international researchers. Barnboken is published with financial support from the Swedish Research Council.

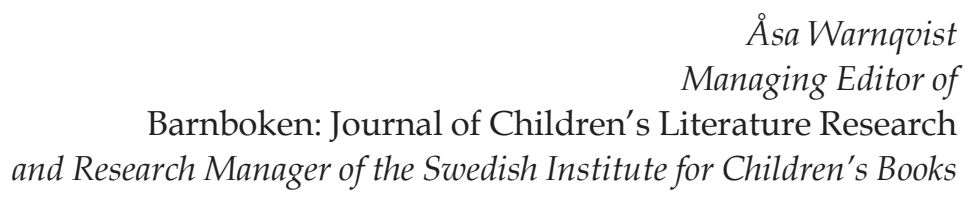

